\title{
Société Canadienne d'Études de la Renaissance / Canadian Society for
Renaissance Studies
}

Annual Meeting of the Canadian Society for Renaissance Studies/Société canadienne d'Etudes de la Renaissance (University of Saskatchewan, Saskatoon, May 23-25, 1979)

At the time this material went to press (ca. February 15) the details of the programme were not definite but we can present the general programme of the Congress.

May 23, morning and afternoon.

The present state of historical studies on the Renaissance, political history, economic history, cultural history etc.

Chairman: Claude Sutto, Institut d'études médiévales, Université de Montréal.

May 24, morning.

Literature. Papers on national literatures or on general literary and linguistic subjects.

Chairman: David Hoeniger, Victoria College, University of Toronto.

May 24, afternoon.

I - Reports on the situation of Renaissance studies in Canada and on projects and perspectives.

II - Business meeting.

May 24 , evening.

Banquet or social meeting

May 25, morning.

Reformation. Projects on the editing of the great authors of the Reformation and other papers.

Chairman: Gerald Hobbs, Vancouver School of Theology.

The congress will end at noon on the 25th in order to permit participants from the East to take the last plane at 3:30 p.m.

The complete programme will be sent out to all the Society's members in good time. 